UDC 378.12:81'243

DOI https://doi.org/10.24919/2308-4863/38-2-21

\author{
Oksana KOVALENKO, \\ orcid.org/0000-0001-8431-5859 \\ Lecturer at the Department of English \\ Petro Mohyla Black Sea National University \\ (Mykolaiv, Ukraine)anglu4itel@gmail.com
}

Tetyana CHERNYUK,

orcid.org/0000-0002-9800-3765

Lecturer at the Department of English

Petro Mohyla Black Sea National University

(Mykolaiv,Ukraine) tatianka.cherniuk@gmail.com

\title{
FORMATION OF HIGH SCHOOL TEACHER'S PROFESSIONAL COMPETENCE
}

The article analyzes research and scientific publications on the personal, professional, and pedagogical qualities of a high school teacher. Professional activity is characterized as a special form of highly qualified, mental activity of a creative nature, aimed at learning, comprehensive development of students, the formation of professional knowledge, skills, abilities and education of an active life position. The article describes the main types of communication between teachers and students, components of the psychological and pedagogical structure, professionalism of teachers and their skills. The requirements to the teacher's personality, his creative approach to the work is outlined, the article also reveals the stages of the process of self-improvement and self-development.

Teacher's professional competence is a set of professional and personal qualities, which are necessary for successful pedagogical activity. A professionally competent teacher is a professional with a sufficiently high level of pedagogical activities, pedagogical communication. It is somebody who achieves consistently high results in teaching.

Professional competence's development is first of all creative individuality, ability to adapt in a changing pedagogical environment. The socio-economic and spiritual development of society directly depends on the professional level of teachers. The changes should take place in the modern education system and make it necessary to improve the qualifications and teacher's professionalism or their professional competence. Their role in the process of professional development is an important part in the innovative activity. Therefore, it is essential for a teacher to be ready for professional development.

If it is not enough for a teacher to work in a traditional system to master pedagogical techniques, but also provide educational activities at a professional level and achieve more or less successful learning. In this case teacher is ready to innovation.

Thus, competence is not a simple sum of knowledge, skills and abilities. It includes cognitive (knowledge), operational (modes of activity and readiness to carry out activities) and axiological (the presence of certain values) aspects. Competence "is a personal characteristic, a set of knowledge, skills, and flexible thinking, and competence in predetermined requirements for the educational training, curriculum, competence "anatomy"; a set of specific professional or functional characteristics".

Key words: pedagogical activity, pedagogical skill, professionalism, creativity, personal qualities, types of communication, psychological and pedagogical structure.

Оксана КОВАЛЕНКО, orcid.org/0000-0001-8431-5859 викладач кафедри англійської мови Чорноморського національного університету імені Петра Могили (Миколаїв, Україна) anglu4itel@gmail.com

Тетяна ЧЕРНЮК, orcid.org/0000-0002-9800-3765 викладач кафедри англійської мови

Чорноморського національного університету імені Петра Могили (Миколаїв, Україна) tatianka.cherniuk@gmail.com

\section{ФОРМУВАННЯ ПРОФЕСІЙНОЇ КОМПЕТЕНТНОСТІ ВЧИТЕЛЯ СЕРЕДНЬОЇ ШКОЛИ}

У статті аналізуються наукові публікаиії про особисті, професійні та педагогічні якості вчителя середньої школи. Професійна діяльність характеризується як особлива форма висококваліфікованої, розумової діяльності творчого характеру, спрямована на навчання, усебічний розвиток учнів, формування професійних знань, умінь, 
навичок та виховання активної життевої позиції. У статті описано основні типи спілкування між викладачами й учнями, складові частини психолого-педагогічної структури, професіоналізм учителів та їхні вміння. Викладено вимоги до особистості вчителя, його творчого підходу до роботи. У статті також розкриваються етапи проиесу самовдосконалення та саморозвитку.

Професійна компетентність учителя - це сукупність професійних та особистісних якостей, які необхідні для успішної педагогічної діяльності. Професійно компетентний учитель - ие професіонал із досить високим рівнем педагогічної діяльності, педагогічного спілкування. Це той, хто досягає стабільно високих результатів у навчанні.

Розвиток професійної компетентності - ие передусім творча індивідуальність, здатність адаптуватися 6 мінливому педагогічному середовищі. Соціально-економічний та духовний розвиток суспільства безпосередньо залежить від професійного рівня викладачів. Зміни мають відбутися в сучасній системі освіти, зробити необхідним підвищення кваліфікації та професіоналізму вчителя або їхньої професійної компетентності. Їхня роль у проиесі професійного розвитку є важливою частиною інновачійної діяльності. Тому вчителю важливо бути готовим до професійного розвитку.

Учителю не досить працювати у традииійній системі для опанування педагогічних технік, а також необхідно забезпечити освітню діяльність на професійному рівні та досягти більш-менш успішного навчання. У цзьому разі вчитель готовий до інновачій.

Отже, компетентність - ие не проста сума знань, умінь та навичок. Вона включає когнітивний (знання), операційний (способи діяльності та готовність до здійснення діяльності) і аксіологічний (наявність певних иінностей) аспекти. Компетентність - «це особиста характеристика, сукупність знань, умінь та гнучкого мислення, а також компетентність у заздалегідь визначених вимогах до навчальної підготовки, навчальної програми; сукупність конкретних професійних або функиіональних характеристик».

Ключові слова: педагогічна діяльність, педагогічна майстерність, професіоналізм, креативність, особисті якості, типи спілкування, психолого-педагогічна структура.

The problem statements. Our work is the formation of personality, and this imposes on us a special, incomparable responsibility (V. Sukhomlinsky). Teaching is a profession that is one of the most creative and complex, which combines science and art. This job is related to the job of a writer, director, actor, educator, psychologist and scientist. The activity and personality of a high school teacher have a social significance and occupy one of the main places in state formation, formation of national consciousness, and spiritual culture of Ukrainian society. The effectiveness of the educational process depends on two main persons "teacher and student", but the educational process can be complete only when it is mutual, when not only the student, but also the teacher is studying and educating. The teacher is the mediator between the students and the teaching material, so he must be ready to act as a mentor and assistant. A person's identity depends on upbringing, on what values will be laid in it. The greatest influence on a person's character is exerted by the family, but no less important is exerted by the teacher. The teacher is responsible for what the next generation will be like, so it is important to know what the teacher should be like.

Successful performance of these tasks is facilitated by the presence of such qualities as a tendency to leadership, desire to help, kindness, responsibility. The image of the ideal teacher originates in philosophical ideas about the teacher of life, who is characterized as a bright, original, creative person, able to feel the problems and contradictions of life. Thus, the personality of a high school teacher is the focus of students. The constant self-improvement and self-development of the teacher play an important role. Conscious self-improvement of the individual and his spiritual growth are eternal categories that have been studied by scientists in different epochs.

The importance of this problem at the present stage cannot be overestimated, because the world around us is constantly changing, and students act as reflectors, which has repeatedly confirmed the historical experience. In recent years, in psychological, pedagogical and sociological research, much attention is paid to the study of the inner world of student youth, their reflections on the environment, and teaching staff.

Analysis of research and publications. An idea of the teacher's personality and his professional activity can be found in scientific works in Ancient Egypt, Babylon, Syria, Ancient Greece. Humanist teachers such as F. Rabelais, M. Montel, T. Moore, and J.-J. Rousseau studied this topic in the Renaissance. K. Ushinsky, A. Makarenko, and V. Sukhomlynsky dealt with this issue among the prominent teachers of our era.

The main characteristics of the teacher, his self-improvement and professional activity are an important issue of modern pedagogy, psychology, sociology. There are numerous scientific discussions of this issue. Characterizing the personality of the modern teacher S. Skorikova writes: "There is no doubt that a teacher, a tutor can fulfill his high mission in the training of modern personnel only when he loves his profession, is convinced of its importance and seeks by all means to form a highly qualified specialist, a decent person". 
N. Kuzmina, K. Levitan, T. Talanchuk - studied the functions of professional and pedagogical activity; O. Kiselyova - personal function of self-education; T. Shestakova - creative, purposeful, independent movement of the specialist to the top of personal and professional development; O. Kucheryavy professional self-education, creative self-movement of the individual to professional self-realization.

V. Adamova and V. Potekhin considers the main feature of a teacher - the ability to navigate well in various fields of science, to be aware of new research, discoveries and to see the short- and long-term prospects of science. At the same time, researchers O. Gura, A. Kozhuyev, O. Moroz, D. Chernilevsky emphasize that the problem of teacher selfimprovement has not become significant.

Most teachers do not realize the importance of personal growth, they believe that a teacher needs to know his subject, and everything else will come with experience. Sociological centers of different Universities annually conduct surveys at various faculties, which contain questions about the attitude of students to teachers and their teaching activities. N. Rozhanska described the results of a sociological study "The ideal teacher through the eyes of students of Petro Mohyla Black Sea National University" in her article. Similar surveys are conducted at many universities in Ukraine and abroad. The results of such surveys and research are almost the same. Students represent an ideal teacher as someone who has a good knowledge of his subject, hold interesting and accessible classes using non-standard teaching methods. An ideal teacher respects the opinion of students and creates a friendly atmosphere. Among the personal qualities' students distinguish: punctuality, responsibility, politeness, justice, professionalism, calm nature. The teacher's appearance should be business style with a neat hairstyle and well-groomed shoes.

The aim of the article. To determine the important personal and professional-pedagogical qualities of a high school teacher, to consider the phenomenon of self-improvement and professional self-realization.

Main material. Pedagogical activity in higher education is an activity aimed at training a qualified specialist who must find his place in the labor market and be actively involved in social, cultural, political, and other spheres of life. The object of pedagogical influence are students with different inclinations, interests, intelligence, feelings. Ukrainian educator Vasyl Sukhomlynsky (1918-1970) noted that in any case mistakes and failures do not lead to such severe consequences as in the pedagogical one. Teachers in their activities have to master the language and speech. K. Ushinsky wrote: "Native language is a great national treasure, the basis of development and the treasury of all knowledge, it begins to understand everything". The word of the native language is a powerful aspect of spiritual contact, moral influence and conviction.

Let us consider what are the types of communication between teachers and students.

1. Primitive. Attitude toward students is reflected in primitive rules and reactions of behavior. The teacher demonstrates his superiority, the student is a means to an end.

2. Manipulative. The teacher's relationship with students is based on the game. Praise is used. The student is the object of manipulation. He is intimidated and infantile.

3. Standardized. The formal communication dominates. The teacher follows the standards of etiquette. Such behavior is superficial as the student feels the indifference of the teacher and remains the object of manipulation.

4. Business. Focusing on the work, the teacher takes into account the personal characteristics of the student only in the context of effective activities. He follows the standards of etiquette and recognizes the student's right to independence. The significance of the student for the teacher depends on the contribution to the joint activity.

5. Personal. Communication is based on the deep interest of students, the teacher loves students, all his activities are aimed at the development of spirituality. The student trusts the teacher, and the teacher is an authority for him.

I. Zazyun distinguishes the following styles of communication: a) authoritarian style. The dictate is used, which turns one of the participants in communicative interaction into a passive performer. An authoritarian teacher arbitrarily determines the direction of the group. This inhibits the initiative, suppresses the activities of students. The main forms of interaction of this style of communication are an order, indication, instruction, reprimand. The teacher is intolerant of objections. All this leads to an unfavorable psychological climate; b) democratic style. It is based on deep respect, trust and focuses on self-organization of the individual and the team. This style is designed to bring the purpose of the activity to the minds of each student and to involve everyone in active participation in the common cause. The main means of interaction are encouragement, advice, information; c) liberal style. In the liberal style the teacher does not have a stable pedagogical position. It is manifested in noninterference and low level of education requirements. Such teacher is limited to performing only the teaching function. The consequence of such a position is a loss of respect, a deterioration in performance and discipline. 
So, it is very important how the teacher communicates with students.

According to V. Sukhomlinsky, the word should heal, not be a whip. Democritus emphasized that everything must be learned "Neither the art of eloquence nor wisdom can be achieved if it is not learned". A high school teacher has a difficult task, to develop love and respect to the native language, the form skills and abilities of correct speech of students. The best way to achieve this goal is your own example.

Pedagogical activity can be divided into several functions. The main one is educational, which is aimed at organizing the learning process. It combines the theoretical basis, the discovery of new patterns. The second is practical, which aims to solve pedagogical problems. The teacher determines the purpose, considers the content of education, modern methods and forms that contribute to the activation of educational and cognitive activities of the student, forms of control. The main types of this activity are lectures, lab works, practical tasks, seminars, consultations, tests, exams, reviews, organization of defense of term papers and projects, management of theses, practice and research. Closely related to educational work is methodical work - it is preparation for lectures, laboratory, practical classes, compilation and preparation for publication of lecture notes, collections of exercises and tasks, laboratory workshops, methodical materials for term papers and dissertations, current work to improve pedagogical skills (reading of methodical, educational, scientific and methodical literature), drawing up of methodical developments, tasks, examination tickets, subjects of course works (Гура, 2006: 330).

In the process of methodical work, the skill level of the teacher increases, as he learns the content of new curricula, gets acquainted with the achievements of psychological and pedagogical sciences and methods of teaching disciplines, studies advanced pedagogical experience, improves his skills of self-education. An important place in the teacher's activities belongs to the organizational and methodological work. It is the work in the preparatory department, in the admissions committee, the organization of pedagogical practices, preparation of materials for meetings of the department council, work on preparation of scientific and methodical seminars. Pedagogical activity should be combined with research, which enriches the inner world, develops creative potential, increases the scientific level of knowledge, encourages new ideas and conclusions.

A good teacher, to master his subject more deeply, gets acquainted with the scientific literature, monitors the development of this science, studies the experience of educational work of his colleagues. Edits scientific and methodical journals.

Educational activities are carried out in the learning process, using all the opportunities of academic disciplines, as well as during extracurricular communication. It is important that each teacher realizes the importance of their educational impact on future professionals and implement this function not only through interviews, curatorial activities, but also by their own example.

The professionalism of the teacher is manifested in the ability to see the analysis of different situations and find ways to solve them. And this requires a creative approach to teaching. To perform pedagogical activities effectively, the teacher must be aware of the main components of the psychological and pedagogical structure, pedagogical actions, skills, and qualities necessary for its implementation. (Гапон, 2009: 110).

Psycho-pedagogical activity structure - a system of teacher's actions to achieve goals through solving educational problems. The following functional components are distinguished in this system (N. Kuzmina): epistemological, constructive, organizational, communicative.

Epistemological (greek word "gnostikos" means "cognitive") component includes the study of each student individually and the whole team, the use of different methods of teaching and education, and learning guidelines. It also includes analyzing their own experience and the experience of other teachers, generalization and application of effective forms, methods and techniques in their work, self-education and self-education. The constructive component involves the selection of educational information to be communicated to students, planning own activities and behaviors to interact with students. The communicative component includes establishing pedagogical relations with those affected (recognition of moral, intellectual and political superiority as a leader and organizer), establishing proper relations with the leaders of this system (discipline, principledness, creativity), correlation of their activities with government tasks (Введенський, 2003: 12).

The psychological structure of the teacher is dynamic and changes with mastery. The teacher needs to win the audience, it depends on the relationship with students.

Pedagogical activity in higher education involves certain requirements for the teacher's personality.

1. Awareness of their civic duty - education of worthy citizens of the country and highly qualified specialists. 
2. Perfect mastery of their subject. According to student surveys, the most authoritative are those teachers who know their subject well. Also, the teacher should be well oriented in related disciplines that promotes deep disclosure interdisciplinary relations, events and realities of the modern world, forming an intelligent expert.

3. Possession of teaching methods that help to make a complex task accessible, taking into account the ability of students to be interested in information, to arouse the desire to replenish their knowledge.

4. Pedagogical expression. This is such an attitude to pedagogical activity and psychological readiness for it. It is manifested in the direction of thoughts, in the manner of speaking, in behavior. Thanks to this feature, the teacher can intuitively distinguish from the environment educational facts and pedagogically convey them to students.

5. Love for students should be reasonable. The famous teacher and an artist Anton Semenovich Makarenko noted that love for students precludes unprincipled and indulgent attitude, indulgence in its weaknesses. In his opinion, demanding does not contradict love and respect for the person.

6. Erudition. In addition to knowledge of his subject, the teacher must have knowledge of philosophy, history, politics, art, modern science and technology. This will help him communicate with students on various topics.

7. Creative approach. Creativity of the teacher is first of all a choice of methods and approaches to realization of the purpose and tasks, maintenance of efficiency of educational process. As well as teaching students to independently obtain information and develop creative thinking, equipping with research skills, education of an experienced and cultured person. The teacher, who is a creative person, analyzes his own experience, studies and takes the best from others, seeks and finds new, more advanced pedagogical technologies. K. Ushinsky determined that a "teacher" lives in a teacher only as long as he studies.

8. High moral qualities. In the moral aspect, the teacher must be the one who seeks to educate their students.

9. Have emotional and volitional behavior. The teacher must be purposeful, proactive, disciplined, demanding to himself and others, to have own feelings.

10. Pedagogical observation and attentiveness. Observing students, the teacher learns about their characteristics, attitudes to learning and teachers, the relationship between them, mental states, their response to comments and assessments. It is necessary to focus on the studied topics and changing the types of tasks and tools.
11. Inspiration and intuition. Inspiration comes to the teacher due to interest in the subject of research, constant reflection, and planning goals. It is a mental state, when all areas of the psyche are involved at the same time: mind, feelings, perception. Intuition is manifested in the feeling of the right activity, in the desire for its results, in the belief that this is the way to act, and not otherwise.

12. Mastery of language and mindset. The language and the mindset of the teacher must be pedagogical, it is about clarity and logic of thought, specificity, intelligibility. The speech should be free of defects (lisp, stuttering, fast or slow pace).

13. Optimism is an integral feature of a modern teacher because it affects the effectiveness of teaching and education of students, creates positive emotions, good condition, activity, determination, excellence in their abilities.

14. Pedagogical tact. This is a professional feature of the teacher's behavior in relations to students, the ability to find the right solution in each case. The teacher needs pedagogical tact in the system of his educational influence both on the student group and on each student individually.

15. Health and appearance. The teaching profession requires a lot of nervous and physical stress, so you need constantly take care of your health. Appearance is also important. The unattractive appearance of the teacher causes a negative attitude of students to the teacher and his discipline.

The teacher's activity combines scientific, teaching, educational and methodical work, i.e., the teacher is a specialist in a particular field of knowledge: teacher, scientist and manager of personal self-improvement. Self-improvement is manifested in constant development, the desire to become better, to achieve high professional goals, to attract the respect of the student audience, to gain pedagogical authority.

The process of self-improvement and teacher development has the following stages:

The first stage is self-knowledge, the teacher analyzes his own activity and identifies shortcomings.

At the second stage there is a formation of an ideal professional image, comparison with outstanding teachers, where professional values are overestimated.

The third stage is the implementation of the selfimprovement program created by the teacher. The teacher goes through self-restraint, deprivation of comfort, overcoming the negative influences that appear on the path to perfection.

At the fourth stage, as a result of the implementation of the self-improvement program, the specialist forms the life philosophy and professional credo, analyses educational, professional and life achievements and corrects the personal activity. (Бex, 2011: 10). 
The fifth stage is the evaluation of the effectiveness of self-improvement work with adjustments for further work.

Constant self-improvement is an important tool for the professional development of the teacher to improve educational activities and educational and pedagogical processes.

Conclusions. The personal qualities of the teacher play an important role in the education and upbringing of young people, because the teacher is constantly in the center of attention of students. The teacher must be a good manager, speaker, psychologist, know a pedagogical and educational process. Also, he should be an expert in his field of science and a scholar in other sciences, love students and his profession. Therefore, given all the above, it is necessary to develop the personality of the teacher: his cultural, cognitive, and spiritual spheres of activity.

\section{BIBLIOGRAPHY}

1. Бех І. Я - як джерело духовного саморозвитку особистості. Педагогіка та психологія. Київ, 2011. № 3. С. 5-16.

2. Введенський В. Моделювання професійної компетентності вчителя. Педагогіка. 2003. № 10. С. 51-55.

3. Гапон Н., Дубняк М. Вчитель очима учнів. Вісник Львівського університету. Серія «Педагогічна». 2009. C. $106-113$.

4. Гура О. Психолого-педагогічна компетентність викладача вищого навчального закладу: теоретикометодологічний аспект : монографія. Запоріжжя : ГУ «ЗІДМУ», 2006. 332 с.

5. Затін I. Психолого-педагогічна модель особистості вчителя середньої школи. Донецьк, 2011. URL: http://vk.com./ doc7983417 46930860? Хеш = 86163f57coa442919a.

6. Зеер Є. Психологія професій : навчальний посібник для студентів університетів. Москва : Академічний проект ; Скатеринбург : Ділова книга, 2003. 336 с.

7. Зимняя I. Ключові компетентності як ефективно-цільова основа компетентнісного підходу в освіті. Ректор університету. 2005. № 6. С. 13-29.

8. Морозов С. Особистість учителя та навчальний процес. Сучасні підходи до проблем виховання студентської молоді. Рівне, 2000.

9. Ворон Дж. Компетентність у сучасному суспільстві: ідентифікація, розробка та впровадження. Пер. англ. Москва : Когіто-Центр, 2002, 396 с.

10. Трафімова Г. Вчитель очима учнів. Інновації в освіті. 2002. № 5.

11. Фіцула М. Педагогіка середньої школи : підручник. Київ : Академвидав, 2006. 35 с.

\section{REFERENCES}

1. Bekh I. D. Ya - yak dzherelo dukhovnoho samorozvytku osobystosti. [I - as a source of spiritual self-development of the individual] Pedahohika ta psykholohiya. Kyiv, 2011. № 3; S. 5-16. [in Ukrainian]

2. Vvedens'kyy V. N. Modelyuvannya profesiynoyi kompetentnosti vchytelya [Modelling of professional competence of a teacher]. Pedahohika. 2003. № 10. S. 51-55. [in Ukrainian]

3. Hapon N., Dubnyak M. Vchytel' ochyma uchniv [Teacher through the eyes of students]. Visnyk L'vivs'koho universytetu. Pedahohichna seriya. 2009. s. 106-113. [in Ukrainian]

4. Hura O. I. Psykholoho-pedahohichna kompetentnist' vykladacha vyshchoho navchal'noho zakladu: teoretykometodolohichnyy aspekt: monohrafiya. Zaporizhzhya: HU “ZIDMU”, 2006. 332 s.

5. Zatin I. M. Psykholoho-pedahohichna model' osobystosti vchytelya seredn'oyi shkoly [Psychological and pedagogical model of personality of a secondary school teacher] (Elektronnyy resurs). Donets'k. 2011. Rezhym dostupu: http://vk.com./ doc7983417 46930860? Khesh = 86163f57coa442919a. [in Ukrainian]

6. Zeer Y̌e. F. Psykholohiya profesiy: navch. posibnyk. Dlya studentiv. universytety. Moskva: Akademichnyy proekt; Yekaterynburh: Dilova knyha, 2003.336 s.

7. Zymnyaya I. A. Klyuchovi kompetentnosti yak efektyvno-tsil'ova osnova kompetentnisnoho pidkhodu v osviti [Key competencies as an effective and targeted basis of the competency approach in education]. Rektor universytetu. 2005 . № 6. S. 13-29. [in Ukrainian]

8. Morozov S. O. Osobystist' uchytelya ta navchal'nyy protses [Teacher's personality and educational process]. Suchasni pidkhody do problem vykhovannya students'koyi molodi. Rivne. 2000 r. [in Ukrainian]

9. Voron Dzh. Kompetentnist' u suchasnomu suspil'stvi: identyfikatsiya, rozrobka ta vprovadzhennya. za z anhliys'koyi [Competence in modern society: identification, development and implementation. for from English]. Moskva: Kohito-Tsentr, 2002, $396 \mathrm{~s}$.

10. Trafimova H. T. Vchytel' ochyma uchniv [Teacher through the eyes of students]. Innovatsiyi v osviti. 2002. № 5 [in Ukrainian]

11. Fitsula M. M. Pedahohika seredn'oyi shkoly: Pidruchnyk. Kyyiv : Akademvydav, 2006. 35 s. 